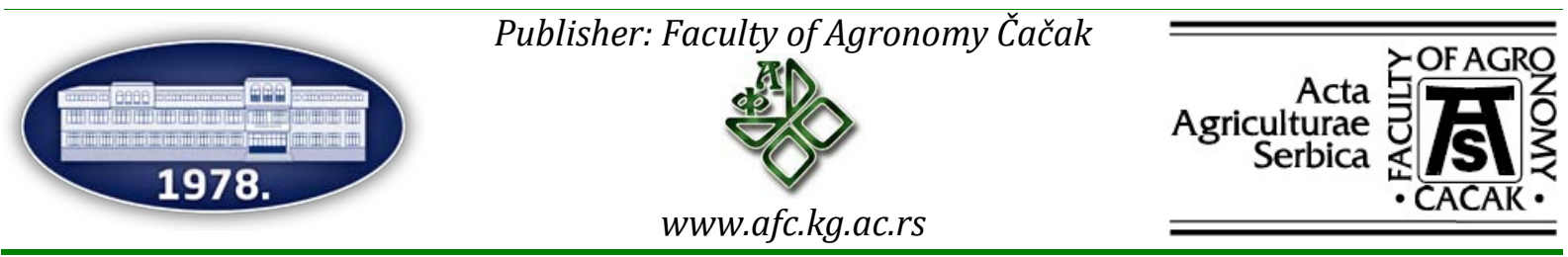

\title{
Sanitary assessment of soil in the municipality of Čačak based on the presence of Escherichia coli and Salmonella sp.
}

\author{
Leka Mandić1 ${ }^{*}$, Dragutin Đukić1, Marijana Pešaković², Vesna Đurović1 \\ 1 University of Kragujevac, Faculty of Agronomy in Čačak, Cara Dušana 34, Čačak, Serbia \\ 2 Fruit Research Institute in Čačak, Kralja Petra 18, Čačak, Serbia \\ *Corresponding author: lekamg@kg.ac.rs
}

Received 28 April 2020; Accepted 1 June 2020

\begin{abstract}
A B S T R A C T
The aim of this study was to assess the sanitary status of soils in the Municipality of Čačak, based on the presence of Escherichia coli and Salmonella sp. The examination involved testing soils previously exposed to different forms of degradation, including soils near industrial zones and landfills, soils close to congested roads,soils exposed to floods, and soils exposed to the uncontrolled use of agrochemicals and agricultural machinery.

The data obtained indicate that the examined soils are mostly unpolluted or slightly to moderately polluted and that therefore they will not have a negative effect on plant production and the health of humans and animals.

Keywords: soil, Escherichia coli, Salmonella sp., sanitary assessment.

И 3 В О Д

У раду је разматран санитарни статус земљишта на територији града Чачка, на основу присуства и бројности Escherichia coli i Salmonella sp. Испитивањем су обухваћена земљишта која су у претходном периоду билиа изложена неком виду деградације: земљишта у близини индустријских зона и депоније; земљишта поред фреквентних саобраћајница; земљишта која су била изложена поплавама и земљишта са неконтролисаном употребом агрохемикалија и пољопривредних машина.

Добијени подаци указују да су испитивана земљишта углавном незагађена или слабо до умерено оптерећена овом врстом загађења и да због тога неће имати негативног ефекта на биљну продукцију и здравствени статус животиња и људи.
\end{abstract}

Кључне речи: земљиште, Escherichia coli, Salmonella sp., санитарна оцена.

\section{Introduction}

Microorganisms are the most important chain in the metabolic activity of soil. They are involved in a number of biological processes, and their numbers and activity have a significant effect on the production capability and the ecological, sanitary and hygienic status of soil (Winding et al., 2005; Yamahara et al., 2012; Mandić, 2019). The total numbers of saprophytes and certain physiological groups of microorganisms, and their enzymatic activity are important indicators of potential and effective fertility of soil (Nannipieri et al., 2003; Đukić and Mandić, 2006). Recently, in addition to the aforementioned characteristics of soil, the assessment of its sanitary and epidemiological status and the identification of soil pollution microbial indicators have been emphasised. Sanitary and epidemiological assessments of soil rely on the use of sanitary and bacteriological indicators -the presence of the causal agents of intestinal infections, pathogenic bacteria, enteroviruses, and sanitation indicator microorganisms; sanitary parasitological indicators the presence of the causal agents of parasitic diseases (geo-helminthiasis, amoebiasis); sanitary toxicological indicators -the contents of chemical pollutants; sanitary chemical indicators (sanitary number, organic matter content), and the presence of fly larvae and pupae (Đukić et al., 2019; Kalwasińska et al., 2012).

One of the most important indicators of the sanitary status of soil is the presence of the faecal bacteria Escherichia coli and Salmonella sp. These bacteria are not typical inhabitants of soil and therefore they are not covered by national regulations on soil quality assessment. In most cases, they are not found in pure soils or their number is very low (coli titre is above 1). As determined by Đukić et al. (2011), values of coli titre are 1.0-0.01 in slightly contaminated soils,0.01-0.001 in moderately contaminated soils, and up to 0.001 in extremely contaminated soils.

Their numbers and survival in the soil depend on several factors (Yamahara et al., 2012), which have to be considered due to the possibility of their penetration into cultivated plants (Đukić at al., 2009) or groundwater, and the resulting harmful effects on the health status of higher organisms and humans in the food chain(Grisey et al., 2010).

The aim of this research is the sanitary assessment of soil in the Municipality of Čačak based on the 
presence and numbers of Escherichia coli and Salmonella sp.

\section{Materials and methods}

Soil testing was performed at the end of 2018 using samples of soils previously exposed to some form of degradation in the Municipality of Čačak. When choosing sampling sites, consideration was given to the fact that suburban and urban areas are mostly polluted from industries, landfills and traffic congestion, and that the most frequent sources of pollution of agricultural soils are the uncontrolled use of agrochemicals (mineral fertilisers, pesticides etc) and agricultural machinery or the influence of weatherrelated natural disasters such as floods. With this in mind and aiming to facilitate the interpretation and analysis of results, the chosen sites were classified into four groups, as follows: soils near industrial zones and landfill (3 sites), soils near congested roads (3 sites), soils exposed to floods ( 2 sites), and soils exposed to the uncontrolled use of agrochemicals and agricultural machinery ( 2 sites) -Tab. 1 .

The soils were sampled using an agrochemical probe from the surface layer up to $30 \mathrm{~cm}$ depth. When sampling, GPS coordinates of the sites were determined.

Three separate soil samples were taken from each site aseptically and transferred to three sterile bags. Air-dried samples were ground and passed through a 2 $\mathrm{mm}$ sieve. Microbiological tests ( determination of counts of E. coli and Salmonella sp.) were performed in the Microbiological Laboratory of the Faculty of Agronomy in Čačak. The numbers of $E$. coli and Salmonella sp. were determined as colony forming units (CFUs) on agar plates by the Serial Dilution Plate method. The media used for the enumeration of $E$. coli and Salmonella sp. were Endo agar and SS agar (Salmonella Shigella Agar), respectively. Plates were incubated at $37^{\circ} \mathrm{C}$ for $24-48$ hours.

The determination of the presence of the aforementioned bacteria was based on colony characteristics and microscopic evaluation. The obtained values were calculated at $1.0 \mathrm{~g}$ absolutely dry soil. The soil pollution status was assessed following the standards reported by Đukić et al. (2011).

\section{Table 1}

Sites chosen for the sanitary assessment of soils in the Municipality of Čačak

\begin{tabular}{|c|c|c|}
\hline Item & Site & $\begin{array}{c}\text { Number of } \\
\text { analysed } \\
\text { samples }\end{array}$ \\
\hline \multicolumn{3}{|c|}{ I Soils near industrial zones and landfill } \\
\hline 1. & Old industrial zone & 9 \\
\hline 2. & New industrial zone & 9 \\
\hline 3. & Landfill & 9 \\
\hline \multicolumn{3}{|c|}{ II Soils close to congested roads } \\
\hline 4. & $\begin{array}{l}\text { Soils close to roadswith } \\
\text { dense traffic, outside the } \\
\text { city zones (locality I) }\end{array}$ & 9 \\
\hline 5. & $\begin{array}{l}\text { Soils close to roadswith } \\
\text { dense traffic, outside the } \\
\text { city zones (locality II) }\end{array}$ & 9 \\
\hline 6. & $\begin{array}{l}\text { Soils close to roadswith } \\
\text { dense traffic, within the } \\
\text { city zones }\end{array}$ & 1 \\
\hline \multicolumn{3}{|c|}{ III Soils exposed to floods } \\
\hline 7. & $\begin{array}{l}\text { Agricultural soil exposed to } \\
\text { floods (locality I) }\end{array}$ & 4 \\
\hline 8. & $\begin{array}{l}\text { Agricultural soil exposed to } \\
\text { floods (locality II) }\end{array}$ & 4 \\
\hline \multicolumn{3}{|c|}{$\begin{array}{l}\text { IV Soils exposed to the uncontrolled use of } \\
\text { agrochemicals and agricultural machinery }\end{array}$} \\
\hline 9. & Orchards & 3 \\
\hline 10. & Arable land & 3 \\
\hline
\end{tabular}

\section{Test results and discussion}

The counts/presence of the tested groups of microorganisms in the soils of the tested sites is presented in Table 2.

Table 2

Sanitary assessment of the examined sites in the Municipality of Čačak, based on average counts of $E$. coli and Salmonella sp.

\begin{tabular}{|c|c|c|c|c|}
\hline $\begin{array}{c}\text { Sample } \\
\text { number }\end{array}$ & GPS $(N)$ & GPS (E) & $\begin{array}{c}\text { E. coli } \\
\left(10^{2} / \mathrm{g}\right) \\
\end{array}$ & Salmonella sp. (25 g) \\
\hline \multicolumn{5}{|c|}{ Solis near the old industrial zone } \\
\hline 1 & $\begin{array}{l}4353.485 \\
4353.477\end{array}$ & $\begin{array}{l}2022.094 \\
2022.105\end{array}$ & $8.1^{* *}$ & - \\
\hline 2 & $\begin{array}{l}4353.525 \\
4353.516\end{array}$ & $\begin{array}{ll}20 & 22.129 \\
20 & 22.150\end{array}$ & $5.3^{* *}$ & - \\
\hline 3 & $\begin{array}{l}4353.573 \\
4353.559\end{array}$ & $\begin{array}{l}2022.167 \\
2022.196\end{array}$ & $7.1^{* *}$ & - \\
\hline 4 & $\begin{array}{l}4353.375 \\
4353.362\end{array}$ & $\begin{array}{ll}20 & 22.142 \\
20 & 22.143\end{array}$ & $3.3^{* *}$ & - \\
\hline 5 & $\begin{array}{l}4353.359 \\
4353.372\end{array}$ & $\begin{array}{l}2022.083 \\
2022.078\end{array}$ & $10.0^{* *}$ & - \\
\hline 6 & $\begin{array}{l}4353.312 \\
4353.315\end{array}$ & $\begin{array}{ll}20 & 22.008 \\
20 & 21.988\end{array}$ & $10.0^{* *}$ & - \\
\hline 7 & $\begin{array}{l}4353.186 \\
4353.184\end{array}$ & $\begin{array}{ll}20 & 22.251 \\
20 & 22.244\end{array}$ & $1.2^{*}$ & - \\
\hline
\end{tabular}




\begin{tabular}{|c|c|c|c|c|}
\hline 8 & $\begin{array}{l}4353.165 \\
4353.163\end{array}$ & $\begin{array}{l}2022.206 \\
2022.212\end{array}$ & - & - \\
\hline 9 & $\begin{array}{l}4353.139 \\
4353.131\end{array}$ & $\begin{array}{ll}20 & 22.174 \\
20 & 22.178\end{array}$ & - & - \\
\hline \multicolumn{5}{|c|}{ Soils near the new industrial zone } \\
\hline 10 & $\begin{array}{l}4353.790 \\
4353.795\end{array}$ & $\begin{array}{l}2025.660 \\
2025.632\end{array}$ & $5^{* *}$ & - \\
\hline 11 & $\begin{array}{l}4353.831 \\
4353.830 \\
\end{array}$ & $\begin{array}{l}2025.708 \\
2025.726 \\
\end{array}$ & $1.8^{* *}$ & - \\
\hline 12 & $\begin{array}{l}4353.888 \\
4353.874 \\
\end{array}$ & $\begin{array}{l}2025.769 \\
2025.797 \\
\end{array}$ & $0.6^{*}$ & - \\
\hline 13 & $\begin{array}{l}4353.857 \\
4353.853 \\
\end{array}$ & $\begin{array}{l}2025.824 \\
2025.842\end{array}$ & $0.6^{*}$ & - \\
\hline 14 & $\begin{array}{l}4353.829 \\
4353.826\end{array}$ & $\begin{array}{l}2025.914 \\
2025.939\end{array}$ & $0.7^{*}$ & + \\
\hline 15 & $\begin{array}{l}4353.781 \\
4353.783\end{array}$ & $\begin{array}{l}2025.929 \\
2025.911\end{array}$ & $2.1^{* *}$ & + \\
\hline 16 & $\begin{array}{l}4353.802 \\
4353.808\end{array}$ & $\begin{array}{l}2025.788 \\
2025.767\end{array}$ & $0.1^{*}$ & + \\
\hline 17 & $\begin{array}{l}4353.742 \\
4353.732\end{array}$ & $\begin{array}{l}2025.872 \\
2025.875\end{array}$ & $22.1^{* * *}$ & - \\
\hline 18 & $\begin{array}{l}4353.759 \\
4353.763 \\
\end{array}$ & $\begin{array}{l}2025.780 \\
2025.748 \\
\end{array}$ & - & - \\
\hline \multicolumn{5}{|c|}{ Soils near the landfill } \\
\hline 19 & $\begin{array}{l}4352.616 \\
4352.629\end{array}$ & $\begin{array}{l}2023.111 \\
2023.080\end{array}$ & $3.1^{* *}$ & - \\
\hline 20 & $\begin{array}{l}4352.642 \\
4352.639\end{array}$ & $\begin{array}{l}2022.988 \\
2023.013\end{array}$ & $10.0^{* *}$ & - \\
\hline 21 & $\begin{array}{l}4352.841 \\
4352.838 \\
\end{array}$ & 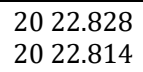 & - & - \\
\hline 22 & $\begin{array}{l}4352.585 \\
4352.591\end{array}$ & $\begin{array}{l}2023.026 \\
2023.000\end{array}$ & - & - \\
\hline 23 & $\begin{array}{l}4352.571 \\
4352.568\end{array}$ & $\begin{array}{ll}20 & 23.146 \\
20 & 23.122\end{array}$ & $0.3^{*}$ & - \\
\hline 24 & $\begin{array}{l}4352.853 \\
4352.862\end{array}$ & $\begin{array}{ll}20 & 22.776 \\
20 & 22.774\end{array}$ & $1.3^{*}$ & - \\
\hline 25 & $\begin{array}{l}4352.578 \\
4352.590\end{array}$ & $\begin{array}{l}2022.919 \\
2022.894\end{array}$ & $50.3^{* * *}$ & - \\
\hline 26 & $\begin{array}{r}4352.520 \\
4352.527 \\
\end{array}$ & $\begin{array}{l}2023.135 \\
2023.118 \\
\end{array}$ & $6.2^{* *}$ & - \\
\hline 27 & $\begin{array}{l}4352.863 \\
4352.864 \\
\end{array}$ & $\begin{array}{l}2022.725 \\
2022.713 \\
\end{array}$ & $2.4^{* *}$ & - \\
\hline \multicolumn{5}{|c|}{ Soils close to roads with dense traffic, outside the city zones (locality I) } \\
\hline 28 & $\begin{array}{l}4356.004 \\
4356.024 \\
\end{array}$ & $\begin{array}{l}2024.449 \\
2024.461 \\
\end{array}$ & $0.4^{*}$ & - \\
\hline 29 & $\begin{array}{l}4355.969 \\
4355.982 \\
\end{array}$ & $\begin{array}{l}2024.581 \\
2024.582\end{array}$ & $0.9^{*}$ & - \\
\hline 30 & $\begin{array}{r}4355.973 \\
4355.989 \\
\end{array}$ & $\begin{array}{l}2024.653 \\
2024.656 \\
\end{array}$ & $0.9^{*}$ & - \\
\hline 31 & $\begin{array}{l}4355.292 \\
4355.287\end{array}$ & $\begin{array}{l}2024.457 \\
2024.444\end{array}$ & $0.2^{*}$ & - \\
\hline 32 & $\begin{array}{l}4355.313 \\
4355.310\end{array}$ & $\begin{array}{ll}20 & 24.361 \\
20 & 24.346\end{array}$ & $4.6^{* *}$ & + \\
\hline 33 & $\begin{array}{l}4355.328 \\
4355.348\end{array}$ & $\begin{array}{ll}20 & 24.282 \\
20 & 24.282\end{array}$ & $1.8^{* *}$ & - \\
\hline 34 & $\begin{array}{l}4355.038 \\
4355.033\end{array}$ & $\begin{array}{l}2024.446 \\
2024.441\end{array}$ & $0.7^{*}$ & - \\
\hline 35 & $\begin{array}{l}4355.049 \\
4355.055 \\
\end{array}$ & $\begin{array}{l}2024.405 \\
2024.411 \\
\end{array}$ & $0.1^{*}$ & - \\
\hline 36 & $\begin{array}{l}4355.059 \\
4355.069\end{array}$ & $\begin{array}{l}2024.360 \\
2024.366\end{array}$ & $0.9^{*}$ & - \\
\hline \multicolumn{5}{|c|}{ Soils close to roads with dense traffic, outside the city zones (locality II) } \\
\hline 37 & $\begin{array}{l}43^{\circ} 51.755 \\
43^{\circ} 51.741\end{array}$ & $\begin{array}{l}2032.660 \\
2032.685\end{array}$ & $8.2^{* *}$ & - \\
\hline 38 & $\begin{array}{c}43^{\circ} 51.688 \\
4351.674\end{array}$ & $\begin{array}{l}2032.847 \\
2032.868\end{array}$ & $8.3^{* *}$ & - \\
\hline
\end{tabular}




\begin{tabular}{|c|c|c|c|c|}
\hline 39 & $\begin{array}{l}4351.401 \\
4351.385 \\
\end{array}$ & $\begin{array}{l}2033.193 \\
2033.209 \\
\end{array}$ & $10.0^{* *}$ & - \\
\hline 40 & $\begin{array}{l}4351.346 \\
4351.341 \\
\end{array}$ & $\begin{array}{l}2033.182 \\
2033.213 \\
\end{array}$ & $6.4^{* *}$ & - \\
\hline 41 & $\begin{array}{l}4351.305 \\
4351.293 \\
\end{array}$ & $\begin{array}{l}2033.152 \\
2033.142 \\
\end{array}$ & $17.1^{* * *}$ & + \\
\hline 42 & $\begin{array}{l}4351.549 \\
4351.553 \\
\end{array}$ & $\begin{array}{l}2032.768 \\
2032.742 \\
\end{array}$ & $2.2^{* *}$ & + \\
\hline 43 & $\begin{array}{l}4351.626 \\
4351.620 \\
\end{array}$ & $\begin{array}{l}2032.563 \\
2032.584 \\
\end{array}$ & $9.3^{* *}$ & - \\
\hline 44 & $\begin{array}{l}4351.614 \\
4351.630 \\
\end{array}$ & $\begin{array}{l}2032.807 \\
2032.820 \\
\end{array}$ & $3.1^{* *}$ & - \\
\hline 45 & $\begin{array}{l}4351.683 \\
4351.678 \\
\end{array}$ & $\begin{array}{l}2032.603 \\
2032.595 \\
\end{array}$ & $8.0^{* *}$ & - \\
\hline \multicolumn{5}{|c|}{ Soils close to roads with dense traffic, within the city zones } \\
\hline 46 & $\begin{array}{l}4352.762 \\
4352.753 \\
\end{array}$ & $\begin{array}{l}2021.237 \\
2021.232 \\
\end{array}$ & $3.3^{* *}$ & - \\
\hline \multicolumn{5}{|c|}{ Agricultural soils exposed to floods (locality I) } \\
\hline 47 & $\begin{array}{l}4354.072 \\
4354.063 \\
\end{array}$ & $\begin{array}{l}2024.299 \\
2024.289 \\
\end{array}$ & $1.0^{*}$ & - \\
\hline 48 & $\begin{array}{l}4353.981 \\
4353.971 \\
\end{array}$ & $\begin{array}{l}2024.455 \\
2024.464 \\
\end{array}$ & $0.7^{*}$ & - \\
\hline 49 & $\begin{array}{l}4353.583 \\
4353.602 \\
\end{array}$ & $\begin{array}{ll}20 & 24.481 \\
20 & 24.461 \\
\end{array}$ & $0.3^{*}$ & - \\
\hline 50 & $\begin{array}{l}4353.948 \\
4353.960 \\
\end{array}$ & $\begin{array}{l}2024.873 \\
2024.843 \\
\end{array}$ & $0.7^{*}$ & - \\
\hline \multicolumn{5}{|c|}{ Agricultural soils exposed to floods (locality II) } \\
\hline 51 & $\begin{array}{l}4351.747 \\
4351.727 \\
\end{array}$ & $\begin{array}{l}2027.835 \\
2027.817 \\
\end{array}$ & $5.1^{* *}$ & - \\
\hline 52 & $\begin{array}{l}4351.493 \\
4351.500\end{array}$ & $\begin{array}{ll}20 & 28.326 \\
20 & 28.298\end{array}$ & $20.2^{* * *}$ & - \\
\hline 53 & $\begin{array}{l}4351.696 \\
4351.673\end{array}$ & $\begin{array}{ll}20 & 28.334 \\
20 & 28.315\end{array}$ & $8.3^{* *}$ & - \\
\hline 54 & $\begin{array}{l}4351.278 \\
4351.299\end{array}$ & $\begin{array}{ll}2028.500 \\
2028.486\end{array}$ & $5.2^{* *}$ & - \\
\hline \multicolumn{5}{|c|}{$\begin{array}{l}\text { Soil exposed to the uncontrolled use of agrochemicals and agricultural machinery } \\
\text { (orchards) }\end{array}$} \\
\hline 55 & $\begin{array}{l}4356.147 \\
4356.136\end{array}$ & $\begin{array}{l}2020.346 \\
2020.373\end{array}$ & $1.6^{*}$ & - \\
\hline 56 & $\begin{array}{l}4355.840 \\
4355.822\end{array}$ & $\begin{array}{l}2021.410 \\
2021.404\end{array}$ & - & - \\
\hline 57 & $\begin{array}{l}4354.981 \\
4354.997\end{array}$ & $\begin{array}{l}2021.855 \\
2021.861\end{array}$ & $3.1^{* *}$ & - \\
\hline \multicolumn{5}{|c|}{$\begin{array}{l}\text { Soil exposed to the uncontrolled use of agrochemicals and agricultural machinery) } \\
\text { (arable land) }\end{array}$} \\
\hline 58 & $\begin{array}{l}4355.850 \\
4355.871\end{array}$ & $\begin{array}{l}2019.561 \\
2019.552\end{array}$ & $4.5^{* *}$ & - \\
\hline 59 & $\begin{array}{l}4356.226 \\
4356.227\end{array}$ & $\begin{array}{l}2022.054 \\
2022.066\end{array}$ & $5.0^{* *}$ & - \\
\hline 60 & $\begin{array}{l}4354.860 \\
4354.858\end{array}$ & $\begin{array}{l}2021.189 \\
2021.168\end{array}$ & $10.0^{* *}$ & - \\
\hline
\end{tabular}

* slightly polluted; ${ }^{* *}$ moderately polluted; ${ }^{* * *}$ extremely polluted/contaminated

+ presence; - absence

The obtained data on the sanitary status of soil (presence/numbers of E. coli and Salmonella sp.) indicate that the examined soils are mostly uncontaminated or slightly to moderately contaminated. Exceptions are soils near the new industrial zone, soils near the landfill, soils close to roads with dense traffic (locality II) and floodplains at locality II (samples nos. 17, 25, 41 and 52, respectively), classified, by the presence of E. coli, asextremely contaminated soils. The occurrence of somewhat higher numbers of E. coli at these sites may be the result of an increased amount of fresh organic waste, faeces of sick animals and birds, and other uncontrolled activities reported by other authors (Yamahara et al., 2012). With regard to Salmonella sp., significant differences were not observed.

Since these groups of microorganisms are not capable of long-term persistence in soil (Recorbet et al., 1993; Gagliardi and Karns, 2002; Đukić et al., 2009, 2011), and since their counts are not significantly high, their current status is not expected to have a crucial effect on the productive capacity of soil and the quality of plant production. However, to prevent the inflow of these microorganisms into the soil and their expansion, 
care must be taken to ensure proper preparation and use of organic fertilisers, acceptable irrigation water quality, proper municipal and industrial waste management, and the use of other sanitary measures which directly or indirectly affect the level of soil contamination.

\section{Conclusion}

The present study reveals that the soil of the Municipality of Čačak exposed to some form of degradation (industrial zones, landfill, soil exposed to floods, soils near congested roads, soil exposed to the uncontrolled use of agrochemicals and agricultural machinery) is mostly uncontaminated or slightly to moderately contaminated with E. coli and Salmonella sp.

The sporadic occurrence of a larger number of $E$. coli in certain soil samples may be attributed to its uncontrolled expansion due to the vicinity of congested roads, industrial zones and landfills.

The studied groups of microorganisms will not have a negative effect on plant production and human and animal health since they are not capable of longterm persistence (survival) and since their numbers are not significantly high.

In order to prevent and mitigate soil contamination and the expansion of these microorganisms in the soil, care must be taken to ensure the use of microbiologically safe manure and the implementation of sustainable industrial and municipal waste management.

\section{Acknowledgement}

This work was supported by the Ministry of Education, Science and Technological Development of the Republic of Serbia, Contracts No. 451-03-68/2020 $14 / 200088$ and 451-03-68/2020-14/200215.

\section{References}

Đukić, D., Jemcev, V.T., Mandić, L. (2011). Sanitarna ocena zemljišta na osnovu mikrobioloških pokazatelja. Sanitarna mikrobiologija zemljišta, Agronomski fakultet u Čačku, 29-32.

Đukić, D., Mandić, L. (2006). Microorganisms as indicators of soil pollution with Heavy metals. Acta Agriculturae Serbica, 11(22), 45-55.

Đukić, D., Mandić, L., Pešaković, M., Novosel, P. (2009). Kolonizacija biljaka sa E.coli u uslovima zagađenog zemljišta. XIV Savetovanje o biotehnologiji, Čačak, 27- 28. Mart. Zbornik radova, 14(15), 23-26.

Gagliardi, J.V., Karns, J.S. (2002). Persistence of Escherichia coli 0157:H7 in soil and on plant roots. Enviromental microbiology, 4(2), 89-96.

Grisey, E., Belle, E., Dat, J., Mudry, J., Aleya, L. (2010). Survival of pathogenic and indicator organisms in groundwater and landfill leachate through coupling bacterial enumeration with tracer tests. Desalination, 261(1-2), 162-168.

Kalwasińska, A., Swiontek-Brzezinska, M., Burkowska, A. (2012). Sanitary Quality of Soil in and near Municipal Waste Landfill Sites. Polish Journal of Environmental Studies, 21(6), 1651-1657.

Mandić, L., Đukić, D., Semenov, A., Vesković, S., Vlajić, S., Đurović, V.(2019). Mikrobiološka ocena sanitarnog stanja zemljišta. 24 Savetovanje o biotehnologiji, Agronomski fakultet u Čačku, 15-16. Mart, Zbornika radova, 351-355

Nannipieri, P., Ascher, J., Ceccherini, M.T., Landi, L., Pietramellara, G., Renella, G. (2003). Microbial diversity and soil functions. European Journal of Soil Science, 54, 655-670

Recorbet, G., Picard, C., Normand, P., Simonet, P. (1993). Kinetics of the Persistence of Chromosomal DNA from Genetically Engineered Escherichia coli Introduced into Soil. Applied and Environmental Microbiology, 59(12), 4289-4294.

Winding, A., Hund-Rinke, K., Rutgers, M. (2005). The use of microorganisms in ecological soil classification and assessment concepts. Ecotoxicology and Environmental Safety, 62(2), 230-248.

Yamahara, K.M., Sassoubre, L.M., Goodwin, K.D., Boehm, A.B. (2012). Occurrence and persistence of bacterial pathogens and indicator organisms in beach sand along the California Coast. Applied and Environmental Microbiology, 78, 1733-1745. 